\title{
Intensive care unit length of stay can be longer due to the low serum vitamin $D$ levels in patients with chronic obstructive pulmonary disease
}

\author{
Ş Ö Keşkek ${ }^{1 *}$, O Altınöz ${ }^{2}$ \\ From ESICM LIVES 2015 \\ Berlin, Germany. 3-7 October 2015
}

\begin{abstract}
Introduction
Vitamin D is an immune modulator hormone which has major effects on nearly all cells of the immune system. The deficiency of vitamin D has been found to be associated with many diseases. Chronic Obstructive Pulmonary Disease (COPD) is a chronic inflammatory pulmonary disease asociated with significant mortality and morbidity. Immune system disorders may aggravate the COPD due to the increased morbidity.
\end{abstract}

\section{Objectives}

In this study we aimed to investigate the effect of serum vitamin d levels on COPD patients'duration of stay in intensive care unit (ICU).

\section{Methods}

This retrospective study was performed in ICU of Adana Numune Training and Research Hospital. A total of 44 patients with COPD were included. Patients had diagnosed with COPD according to the GOLD 2011 report. The study and control groups included 23 and 21 patients with vitamin D deficiency or optimal vitamin D status, respectively. Serum $25(\mathrm{OH})$ D concentrations were used for vitamin D levels. Patients with different diseases in addition to the COPD were excluded. FEV1/FVC, FEV, serum creatinine levels and duration of stays in ICU were recorded and compared. MedCalc 15.2.2 (MedCalc Belgium) statistical software was used for statistical analysis.Chi-square is used to test the statistical significance of differences in frequencies. T test or Mann Whitney $\mathrm{U}$ tests were used for comparison of quantitative measurements between the two groups.

${ }^{1}$ Numune Training and Research Hospital, Internal Medicine, Adana, Turkey Full list of author information is available at the end of the article

\section{Results}

The groups were matched in terms of age and sex $(\mathrm{p}=0.65,0.931$, respectively). FEV1/FVC, FEV1 and serum creatinine levels were comparable in both groups $(\mathrm{p}=0.255,0.393,0.372$, respectively). The levels of serum vitamin D were $14.7 \pm 4.0$ and $39.7 \pm 11.1$ in the study and control groups, respectively $(\mathrm{p}<0.001)$. Duration of stay in ICU was longer in COPD patients with low serum vitamin D levels $(9.1 \pm 3.2$ vs. $6.7 \pm 4.1, \mathrm{p}=0.033)$.

\section{Conclusions}

Vitamin D deficiency may aggravate COPD and lead to stay longer in ICU. Patients with COPD should be investigated for vitamin $\mathrm{D}$ deficiency. As an immune modulator vitamin $\mathrm{D}$ can protect $\mathrm{COPD}$ patients against co-morbidities such as infections. Therefore, supplementation of vitamin D can relieve the severity of disease and shorten the length of ICU stay.

\section{Grant Acknowledgment}

The authors have no conflicts of interest.

\section{Authors' details \\ ${ }^{1}$ Numune Training and Research Hospital, Internal Medicine, Adana, Turkey.}

2Defne Hospital, Pulmonology, Antakya, Turkey.

Published: 1 October 2015

\section{References}

1. Holick MF: Vitamin D deficiency. N Engl J Med 2007, 357(3):266-281.

2. Deluca HF, Cantorna MT: Vitamin D: its role and uses in immunology. FASEB J 2001, 15(14):2579-2585.

\section{doi:10.1186/2197-425X-3-S1-A184}

Cite this article as: Keşkek and Altınöz: Intensive care unit length of stay can be longer due to the low serum vitamin $D$ levels in patients with chronic obstructive pulmonary disease. Intensive Care Medicine Experimental 2015 3(Suppl 1):A184. (c) 2015 Altınöz et al.; This is an Open Access article distributed under the terms of the Creative Commons Attribution License (http:// creativecommons.org/licenses/by/4.0), which permits unrestricted use, distribution, and reproduction in any medium, provided the original work is properly cited. 